\title{
Monetary Reward System and Employee Motivation: Empirical Evidence on Management Institution in NCR
}

\author{
Dr. Annu Tomar ${ }^{1}$, Sarthak Sengupta ${ }^{2}$ \\ ${ }^{1}$ Assistant Director (HR), Adbrrigade Marketings Pvt.Ltd. \\ ${ }^{2}$ Research Scholar, Indian Institute of Information Technologuy- Allahabad, Prayagraj \\ Iannutomar27@gmail.com, ${ }^{2}$ sarthak388@gmail.com
}

\begin{abstract}
The reason to conduct this research study is to demonstrate the direct link of the various incentives to the employees for their motivation and also to know to what extent various rewards or incentives are utilized in the private and public organizations to motivate the employees. This study reveals the relationship between incentives such as participation in decision making, favorable climate, salary, bonus, etc. and employees' motivation in any organization. To realize the objectives of this paper, a survey study was administered on the teaching staff of various management institutions in NCR. The relevance of this study is very much attractive and going to be popular for academia because monetary rewards are the best majority of people and one and only common incentive for all employees to attract and retain. In the methodology, a structured questionnaire used for data collection instruments. Both descriptive and exploratory statistics were used to analyze and interpret data of around 100 samples collected through random and convenience sampling. On the basis of previous research and current findings, a triangulation model on the employer branding process has been developed and presented.

As indicated by the aftereffects of the examination, a large portion of the representatives imagine that the degree of usage of the fiscal impetuses in their association is lacking. Likewise, the discoveries recommend that the estimation of financial motivating forces as much as non-money related motivators. Along these lines, inside the confinements of the study, it might be presumed that financial impetuses or prizes can possibly build the inspiration of faculty in general society and private association. It is additionally discovered that among all the money-related impetuses or prizes 'reward and motivators' is the most significant motivating force to rouse the representatives in the association.
\end{abstract}

Index Terms-Incentives, Motivation, monetary rewards (Bonus and Incentive).

\section{INTRODUCTION}

$\mathrm{M}$ OTIVATION is that force in any organization which can convert the passive employees in an active form. At present, every organization believes in hiring and maintaining the talent in the organization by providing them various incentives and appreciation instead of firing the employees immediately. The objective to conduct the study is to identify the impact of various rewards used by various management institutions to motivate the employees in the $\mathrm{Na}$ tional Capital Region. The study also attempts to assess the relationship between monetary and non-monetary motivational rewards and to know the most effective rewards to motivate the employees. The survey and analysis provides a panoramic view of the monetary reward system and em- ployee motivation in management institutions of NCR region.

\section{METHODOLOGY}

In the methodology, a structured questionnaire was used for data collection instruments. Both descriptive and exploratory statistics were used to analyse and interpret data of around 100 samples collected through random and convenience sampling.

The hypothesis behind this is to show a direct correlation of financial incentives and employees encouragement in any organization.

\section{ANALYSIS AND FINDINGS}

The findings of this research are focused on the primary collection of data to analyze the questionnaire of 100 respondents. The data collected from the respondents on the percentage of incentives are given in Table 1. An incentive or reward which motivates the employees more in any private or public organization is the result to be pondered upon and found.

TABle 1: Percentage of InCENTIVES (COLLECTED FROM RESPONDENTS' DATA)

\begin{tabular}{|l|l|l|}
\hline S.NO & INCENTIVES & $\begin{array}{l}\text { PERCENTAG } \\
\text { E }\end{array}$ \\
\hline A & $\begin{array}{l}\text { Professional } \\
\text { development }\end{array}$ & 25 \\
\hline B & Bonus and incentive & 48 \\
\hline C & Salary & 25 \\
\hline D & Flexible work schedule & 02 \\
\hline
\end{tabular}

As we know that there are two main factors to motivate the employees in any of the organizations, i.e., monetary factor and non-monetary factor. So in the analysis of the above-mentioned question, it is observed that maximum percentage $(48 \%)$ of employees is saying that bonus and incentive is the most appropriate method to motivate the employees in the organization. The immediate next percentage goes to the professional development and salary i.e. (25\%) and at last, the least scoring percentage $(2 \%)$ goes to the flexible work schedule. Figure 1 shows the percentage of incentives' histogram plot of the data collected from the re- 


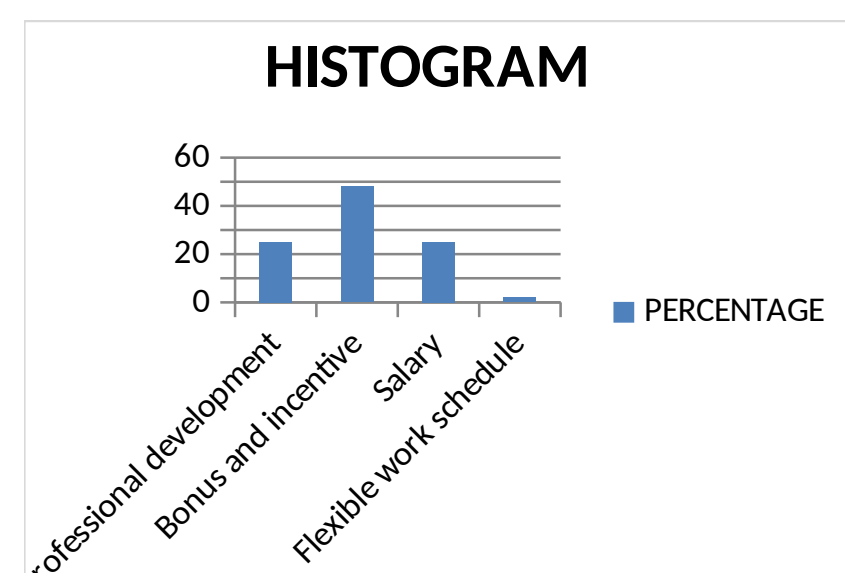

Figure 1: Histogram Plot of the Incentives' Percentage

spondents. This is the result of overall employees in the teaching fraternity of private and public organizations.

\section{CONCLUSION}

To conclude the result and findings of this paper and the above study, it is observed that "bonus and incentive" is one of the best motivational factors in monetary terms. After doing the depth study of the various questionnaires it is further observed that employees are not always motivated by providing various fringe benefits in terms of non-financial rewards instead of financial which is also as crucial as non-financial rewards. Monetary and non-monetary both rewards move simultaneously. So, based on the above-mentioned table and pie chart, it is totally clear that bonus and incentive is one of the best methods to motivate the employees in any organization. Each and every employee needs and demands more and more bonuses and incentives in the organization to give a high level of output and productivity and also to maintain the organization's goodwill. So, in that case, monetary rewards especially the bonus and an incentive is a crucial role player in the life of each employee and enterprise as well.

\section{REFERENCES:}

[1] International Journal of Business and Management Invention ISSN (Online): 2319 - 8028, ISSN (Print): 2319 - 801X www.ijbmi.org Volume 2 Issue $1 \|$ January. 2013\| PP.105-112, www.ijbmi.org

[2] To identify the employees' motivation of Parsian hotels in Tehran (The 2nd half of 2011) Dorrin Pessaran, Sasan Seyed Tavakoli, Master program, Business Administration, Luleå University of Technology, Department of Business Administration, Technology and Social Sciences.

[3] DR.Bedi And Dr..R.K.Ghai, Human resource management, Bharti publication, 110093.

[4] Kumar Pradeep, "elements of personnel management" KedarNath Ram Nath\& co., Meerut.

[5] P. SubbaRao, Management and OrganizationalBehavior, Himalaya Publishing House, Delhi (2007).

[6] Tripathi, P.C., Human Resource Development, Sultan Chand \& Sons, educational publishers, New Delhi.

[7] Mitchell, T. R. (1982). Motivation: New directions for theory research and practice. Academy of Management Review, 7 (1), 80.

[8] Arnolds CA, Venter DJ (2007). The Strategic Importance of Motivational Rewards. Port Elizabeth: Nelson Mandela Metropolitan University,(Unpublished dissertation). Harunavamwe and Kanengoni ,3935

[9] Bagraim J, Cunnington P, Portgieter T, Viedge C (2007). Organizational Behavior a contemporary South African Perspective. Pretoria: Vanschaik Publishers.

[10] Bateman TS, Snell F (2007). Management, Leading and collaborating in a competitive world. McGraw-Hill: Boston.

[11] Bates S (2006). Top Pay for Best Performers. Annual Editions. Hum. Resourc., 31: 130-134.

[12] Daft RL, Marcic D (2007). Management: The New Workplace. South Western: Mason Ohio Thompson.

[13] Shivani Agarwal, Pooja Garg, \& Renu Rastogi (2019). "Subjective well-being: gender differences in Indian IT sector", International Journal of Organizational Behaviour, IUP, Vol. 18, No. 3, 1-18 (Peer reviewed' journal indexed on Cabell's Directory, and EBSCO and Proquest Database). ISBN: 978-81-314-2793-4 